\title{
A Survey on the Endowment Insurance of Flexible Employees in Chongqing
}

\author{
Tan Yong \\ Chongqing Business Vocational College, Chongqing, 400036, China
}

\begin{abstract}
As a young direct-controlled municipality of a large city, vast mountains and reservoir areas, Chongqing is characterized by its typical dual-economic structure. In recent years, with its economic restructuring, the population of individual businesses and migrant workers has been increasingly larger and larger, and their social security has been improved. As one of the basic social security, the endowment pension of flexible employees is of great importance.
\end{abstract}

Keywords: social security, endowment insurance, flexible employees, Chongqing, survey

1. The history of flexible employees' endowment insurance policy in Chongqing

\subsection{The launch of social insurance policies}

The pension policy of flexible employees in Chongqing has been implemented and improved according to relevant state policies and strategies. In 2001, the Ministry of Labour and Social Security issued Circular on Improving the Basic Pension Policy of Urban Employees which provides that self-employed person, like individually-owned businesses, and the flexible employees should continue their pension insurance in accordance with the social insurance base and ratio set by provincial governments.
In 2003, Chongqing Labour and Social Security, Chongqing Local Tax Bureau and Chongqing Finance Bureau jointly issued Interim Measure of Individual Participation of Endowment Insurance in Chongqing and stipulated that workers who have Chongqing residency and have an age between 16 to the retirement age but are not covered by Chongqing endowment insurance of employees can participate in the endowment insurance of urban employees with a payment base of $60 \%$-- $300 \%$ of average monthly wage of previous year and a payment ratio of $18 \%$. Meanwhile, the personal account of endowment insurance should be established. When the premium payment period reaches 15 years and the retirement age is reached, an individual participating in basic pension insurance may collect basic pension on a monthly basis. This interim measure provides basis for flexible employees to participate in endowment insurance.

\subsection{The payment of endowment in-} surance

In the December of 2005, the State Council issues Decision of Perfecting Endowment Insurance System of Urban Employees, and unified the endowment insurance policy of local flexible employees. In the same year, the Chongqing Bureau of Labour and Social Insurance issued Circular of Individual Participation of Endowment Insurance for Enterprise Employees, which covers more people and clarifies that "workers under the national legal retirement age with Chong- 
qing residency should participate in the basic endowment insurance for urban employees". The flexible employees can make a supplementary payment and the payment date should be earlier than July 1st, 2003 or the payment period be longer than 5 years. The payment base and proportion should be fulfilled according to responding standards.

In February, 2006, the Chongqing Bureau of Labour and Social Insurance and the Chongqing Bureau of Finance jointly issued Circular of Adjusting the Payment Cost Standards and Personal Account of Endowment Insurance of Employees and pointed out that the individual payment base should be the average monthly wage of the previous year and the ratio is $20 \%$ from January 1st, 2006.

In December, 2006, the Chongqing Bureau of Labour and Social Security issued another circular which clarifies the necessary materials for urban individuallyowned businesses with rural residency to participate in social insurance and makes specific regulations for men over 60 years and women over 50 years who participate in or renew social insurance.

\subsection{The improvement and implemen- tation of endowment insurance}

Due to the transition and adjustment of payment base, it is more achievable for flexible employees to participate in the endowment insurance. However, the medium and low income workers are facing the risk of bigger proportion. In December, 2008, the Chongqing Bureau of Labour and Social Security and the Chongqing Finance Bureau jointly issued Circular of Adjusting the Payment Base of Endowment Pension Insurance of Employees, by which workers can apply for choosing a certain ratio between $60 \%$ and 100\% from January 1st, 2009.

Then, the Chongqing Human Resources and Social Security Bureau and the Chongqing Finance Bureau jointly issued Opinions on Certain Matters of Basic Pension Insurance of Employees, which clarified that the supplementary payment, including the principal and interest of personal account and coordinated pension, of basic pension insurance within 5 years should be calculated by the Chongqing Labour and Social Security documents [2006]248. For the supplementary period which exceeds 5 years, the supplementary payment should be calculated by the average annual salary of previous year and payment ratio. But the interests of personal account and coordinated pension and overdue fine are exempted. When the supplementary payment has been settled, the local social security administration department will calculate and transfer the savings into personal account. However, the transferring and continual of basic pension insurance should be subject to the unified state regulations.

In conclusion, from the documents of endowment insurance for flexible employees in Chongqing, relevant measures and policies are been improved and perfected, which have greatly promoted them to participate in endowment pension insurance. However, the instability of flexible employees' work hinders their transferring and continual.

\section{The comparison of the population of insured flexible employees in Chongqing and surrounded cities}

Incited by these policies, the endowment insurance of flexible employees of Chongqing has developed from nothing and been increasingly improved.

\subsection{The steadily raising insurance rate}

In spite of the wait-and-see and sluggish attitude, the flexible employees have become more active and initiative in partic- 
ipating in basic pension insurance. In recent years, as the Chongqing Municipality Government has attached great importance on the old-age insurance work and strengthened publicity, citizen's consciousness of endowment insurance is enhanced and there are more and more individual participation in old-age insurance. Since 2010, the population of indi- vidual participation in endowment insurance accounts for half of employees of individually-owned and privately-owned businesses. The List 1 shows that the insurance rate of flexible employees in Chongqing has increased 17\% from 2008 to 2009 due to the improvement of relevant policies. There is a steady growth between 2009 and 2011, too.

\begin{tabular}{|l|l|l|l|l|}
\hline Year & 2008 & 2009 & 2010 & 2011 \\
\hline $\begin{array}{l}\text { Urban privately and individually owned } \\
\text { business (million) }\end{array}$ & $\begin{array}{l}2.48+ \\
1.27\end{array}$ & $\begin{array}{l}2.60+ \\
1.52\end{array}$ & $\begin{array}{l}1.97+ \\
1.94\end{array}$ & $\begin{array}{l}2.06+ \\
2.31\end{array}$ \\
\hline $\begin{array}{l}\text { Ratio of urban privately and Individual- } \\
\text { ly owned business(\%) }\end{array}$ & 54.42 & 57.40 & 53.31 & 55.29 \\
\hline Flexible employees (million) & 4.82 & 5.09 & 5.39 & 5.69 \\
\hline $\begin{array}{l}\text { Number of individual participation in } \\
\text { social insurance(million) }\end{array}$ & 0.86 & 1.35 & 1.14 & 1.22 \\
\hline $\begin{array}{l}\text { Ratio of individual participation in so- } \\
\text { cial insurance(\%) }\end{array}$ & 34.63 & 51.82 & 57.73 & 59.33 \\
\hline
\end{tabular}

Figure 1 individual participation of urban social insurance from 2008-2011 in Chongqing

(Data from Chongqing Statistical Yearbook.2009,2010,2011,2012,electronic edition, Statistical Yearbook of National Bureau of Statistics, http://www.stats.gov.cn/tjs j/ndsj/2012/indexch.htm, Chongqing Bureau of Social Insurance, collected and organized by the research group. The population of flexible employees $=$ the population of informal employees $=$ the whole amount of employment - the population of state-owned enterprise or institution employment - the population of joint-owned enterprise, shareholding economy, and other enterprises. This formula originates from $\mathrm{Hu}$ Angang' s

research.)

2.2. The insurance coverage of this year. As figure 2 shows, both the avChongqing can be further im- erage Gross Domestic Product and averproved

Compared with other direct-controlled municipalities and surrounding cities, the overall coverage of endowment insurance of flexible employees in Chongqing can be further enhanced though the number of insured flexible employees remains stable age annual salary of Chongqing are higher than surrounding cities while the population of endowment insuraced of urban enterprises employees is relatively smaller, which suggests that there are large amount of flexible employees and it is difficult to achieve overall coverage.

\begin{tabular}{|c|c|c|c|c|c|c|c|c|}
\hline Province/ city & Chongqing & Beijing & Shanghai & Tianjin & Sichua & Shanxi & Hunan & $\begin{array}{l}\text { Gui- } \\
\text { zhou }\end{array}$ \\
\hline $\begin{array}{l}\text { Urban Employment } \\
\text { (million) }\end{array}$ & 3.37 & 6.86 & 4.97 & 2.68 & 6.14 & 3.94 & 5.51 & 2.41 \\
\hline $\begin{array}{l}\text { Urban privately- } \\
\text { individually-Owned } \\
\text { employment } \\
\text { (million) }\end{array}$ & $1.22 / 2.33$ & $0.59 / 2.1$ & $0.3 / 3.38$ & $0.35 / 0.94$ & $2.48 / 1.95$ & $1.21 / 1.26$ & $2.56 / 2.35$ & $0.63 / 0.54$ \\
\hline $\begin{array}{l}\text { Urban flexible } \\
\text { employment } \\
\text { (million) }\end{array}$ & $\begin{array}{l}\text { a } 2.43 \\
\text { b1.43 }\end{array}$ & $\begin{array}{l}\text { a3.7 } \\
\text { b0.46 }\end{array}$ & $\underset{\mathrm{b} \rightarrow \mathrm{A}}{\mathrm{A} 0.28}$ & $\begin{array}{l}\text { a1.23 } \\
\text { b1.99 }\end{array}$ & $\begin{array}{l}\text { a8.3. } \\
\text { b3.6. }\end{array}$ & $\begin{array}{l}\text { a } 2.53 \\
\text { b- }\end{array}$ & $\begin{array}{l}\text { a8.94 } \\
\text { b3.67 }\end{array}$ & $\begin{array}{l}\text { a3.28 } \\
\text { b1.96 }\end{array}$ \\
\hline $\begin{array}{l}\text { The number of urban } \\
\text { insured } \\
\text { (million) }\end{array}$ & 6.48 & 215.65 & 13.83 & 4.59 & 14.94 & 5.89 & 9.88 & 2.82 \\
\hline $\begin{array}{l}\text { Average } \\
\text { GDP and } \\
\text { ranking }\end{array}$ & $\begin{array}{l}34705 \text { yuan, } \\
12\end{array}$ & $\begin{array}{l}81581 \text { yu } \\
\text { an, } 3\end{array}$ & 83390 yuan, & $\begin{array}{l}86496 \text { yu } \\
\text { an, } 1\end{array}$ & $\begin{array}{l}26147 \text { yu } \\
\text { an, } 24\end{array}$ & $\begin{array}{l}33196 \text { yu } \\
\text { an, } 15\end{array}$ & $\begin{array}{l}29894 \text { yu } \\
\text { an, } 20\end{array}$ & $\begin{array}{l}16117 \text { yu } \\
\text { an, } 31\end{array}$ \\
\hline $\begin{array}{l}\text { Average annual salary } \\
\text { (yuan) }\end{array}$ & 40042 & 56061 & 51968 & 42240 & 37924 & 39043 & 35520 & 32949 \\
\hline $\begin{array}{l}\text { Average Annual } \\
\text { Salary of urban areas } \\
\text { privated. } \\
\text { Enterprise(yuan) }\end{array}$ & $\begin{array}{l}39430 \\
/ 26251\end{array}$ & $\begin{array}{l}75482 \\
134235\end{array}$ & $\begin{array}{l}75591 \\
25880\end{array}$ & $\begin{array}{l}55658 \\
29547\end{array}$ & $\begin{array}{l}37330 \\
/ 22175\end{array}$ & $\begin{array}{l}38143 \\
18844\end{array}$ & $\begin{array}{l}34586 \\
/ 21483\end{array}$ & $\begin{array}{l}36102 \\
/ 23006\end{array}$ \\
\hline
\end{tabular}

Figure 2 Comparison of the population of endowment insurance of urban enterprises employees

(Statistical Yearbook of National Bureau of Statistics , 2012,electronic edition, http://www.stats.gov.cn/tisj/ndsj/2012/indexch.htm, collected and organized by the research group. a: the population of flexible employees $=$ the whole amount of urban employment - the population of state-owned enterprise or institution employment - the population of joint-owned enterprise, sharehold ing economy, and other enterprises; b: the population of flexible employees = the whole amount of urban employmees - the population of urban institutional employmees the population of privately- and individually- owned enterprises employmees.) 
3. The endowment insurance popularity of flexible employees in Chongqing

For more information about the pension popularity of flexible workers, the research group has made a questionnaire survey for the December of 2012 to the June of 2013 on the social insurance of flexible workers in the main urban zone of Chongqing. During this survey, 2500 questionnaire have been handed out and 2469 ones have been collected.

\subsection{The consciousness of participat- ing in social insurance}

Among 2,469 flexible employees of this survey, 1,872 ones who have joined in endowment insurance and accounts for 75.82 percent and 597 are uncovered by pension insurance and accounts for 24.18 percent, which shows that flexible employees of Chongqing have a strong consciousness of old-age insurance.

\subsection{The categories of insurance}

Among 1872 insurants of flexible employees, there are 458 insurants participating in basic pension insurance for urban employees and accounts for 24.47 percent, 688 insurants in new rural social old-age insurance and accounts for 36.75 percent, and 323 insurants in endowment insurance for urban residents and accounts for 17.25 percent. This shows that there are various kinds of endowment insurance for flexible employees in Chongqing and not all of them choose the basic pension insurance for urban employees.

\subsection{The information channels of pen- sion insurance}

There are 435 respondents who know about information of endowment insurance from social insurance agencies and accounts for 22.7 percent, 404 respondents from friends and relatives and ac- counts for 20.5 percent, 317 respondents from propoganda materials and accounts for 16.08 percent, 253 respondents from radio and television and accounts for 17.86 percent, 176 respondents from newspaper and 287 respondents from other channels and accounts for 14.56 percent. It is evident that the propaganda of social insurance agencies has been working.

3.4. The ratio of insurance fee payment to basic income

There are 783 respondents who have a $5-10$ percent ratio of endowment insurance fee payment to their basic income and accounts for 43.94 percent, 708 respondents whose ratio is below 5 percent and accounts for 39.73 percent, 291 respondents whose ratio is above 10 percent and accounts for 16.33 percent and 90 respondents made no choice. From the survey, most insurants are among the 510 percent ratio group and the endowment insurance fee payment is a certain burden for them.

\subsection{The understanding of pension in- surance standards}

From the survey, there are 626 respondents who are willing to pay 50-70yuan monthly for the old-age insurance and accounts for 35.17 percent, 458 respondents to pay $30-50 y u a n$ monthly and accounts for 25.73 percent, 306 respondents to pay less than 30yuan monthly and accounts for 17.19 percent, 390 respondents to pay $70-90 y u a n$ monthly and accounts for 21.91 percent, and 92 respondents made no choice. The ideal premium of endowment insurance for flexible employees is less than 100yuan monthly.

\subsection{The rights of pension insurance}

There are 187 respondents who regard the pension as "high" and accounts for 7.57 percent, 610 who regard the pension as "right" and accounts for 24.71 percent, 980 who regard the pension as "low" and 
accounts for 36.69 percent and 692 who are unclear about their pension and accounts for 28.03 percent. There are room for improvement for the standards of flexible employees' interests and rights.

\subsection{The claiming of pension insur- ance}

There are 1158 respondents who have no idea of drawing their pension and accounts for 61.84 percent, only 714 know about this and accounts for 22.76 percent. This shows that most flexible employees are unclear about the claiming of old-age pension and further publicity is necessary.

\subsection{The continuing of pension insur- ance}

About the continuing of old-age insurance, 437 respondents prefer to continue and accounts for 23.34 percent; 691 respondents will make efforts to continue and accounts for 36.91 percent; 586 will decide to continue or not acceding to their future income and accounts for 31.3 percent and 158 will not continue their pension insurance and accounts for 8.44 percent. It is reasonable for Chongqing flexible employees to continue their endowment insurance and most would endeavor to continue.

\subsection{The satisfaction of the old-age in- surance}

There are 89 respondents who are very satisfied with the current endowment insurance and accounts for 4.75 percent of the surveyed flexible employees; there are 276 respondents who are satisfied and accounts for 14.74 percent; 1143 are basically satisfied and accounts for 61.06 percent and 364 are unsatisfied and accounts for 19.44 percent. Therefore, the current policies of endowment insurance is basically accepted and recognized by the public.

\section{Conclusion}

From the data analysis and survey, it can be observed that the endowment insurance of flexible workers in Chongqing is comparatively well due to its increasing amount of insurants and satisfaction, but there is still room for improvement.

Firstly, the expenses of old-age insurance. Due to the instability of position and remuneration of flexible employees, their contribution of endowment insurance accounts for a relatively higher ratio of their income. Thus, their pension is comparatively less and can not offset the constantly raising living standards.

Secondly, the continuing and transferring of old-age insurance. Although it is achievable for the continuing and transferring of flexible employees' pension in overall developed counties and towns, certain institutions are unwilling to share their responsibilities. In addition, there is large span to transfer social insurance between different enterprises and public institutions.

Thirdly, the popularity and publicity of old-age insurance. Due to their low literacy and closed environment, they are unclear about the laws and regulation of social insurance. Thus, it is necessary to strengthen the publicity and expand the publicity methods.

Therefore, it is necessary to further adjust the endowment insurance policies of rural and urban areas, improve the working system, strengthen the business capability and make great efforts to promote flexible workers' participation in pension insurance.

(Remarks : this article is one of research results in research on the construction of the social security system for the flexible employment personnel in Chong qing belonging to the science and technology research projects 2012 including 
education commission of Chongqing municipality, the item number: KJ133601.)

\section{References}

[1] Hu Angang, Zhao Li, "The Urban Infromal Employment and Economy in Transitional China(1990- 2004)", Journal of Tsinghua University(Social Sciences,pp. 111-119, 2006.

[2] Chongqing Statistical Yearbook(2009,2010,2011,2012,electronic edtion,

http://www.cqtj.gov.cn/html/tjsj/tjnj/

[3] Statistical Yearbook of National Bureau of Statistics(2012,electronic edition),

http://www.stats.gov.cn/tjsj/ndsj/2012 /indexch.htm 